\title{
Perbandingan efektivitas asam perasetik dan feracrylum pada pola kuman ulkus diabetik
}

\author{
Angelica M. J. Wagiu \\ Richard M. Sumangkut \\ Heber B. Sapan \\ Louise A. J. Waworuntu
}

\author{
Bagian Ilmu Bedah Fakultas Kedokteran Universitas Sam Ratulangi Manado \\ RSUP Prof. Dr. R. D. Kandou \\ Email: angelsurgery@gmail.com
}

\begin{abstract}
Diabetic ulcer is a condition of infection, ulceration, and or destruction of inner skin tissue related to neurological disorders and degrees of peripheral arterial disease (PAD) in diabetic patients. Diabetic ulcer is prone to infection due to decreased immune response, therefore, opportunistic microbes can become pathogens. Infection is sttill a serious problem in diabetic ulcer since the high cost and long duration of treatment lead to complicated neclected ulcer. This study aimed to obtain the present profile of microbes in diabetic ulcers and the effectivitveness of peracetic acid dan feracrylum in the treatment of diabetic ulcers. This was a descriptive analytical study. The ulcer degree was determined by using PEDIS criteria. Pus specimen was taken with a sterile technique using a transport media, cultured in the Baxtec machine, and the microbes were identified and further tested for sensitivity to peracetic acid dan feracrylum $1 \%$. The results showed that of the 57 patients there were 36 females with a mean age of $58.77 \pm 9.077$ years. Most of the patients (30 patients) had diabetic ulcers of 4th degree. The result of pus culture showed Gram negative Proteus mirabilis as the most frequent microbe (17.5\%). The sensitivity test showed that $100 \%$ of 12 types of microbes, $83.3 \%$ of Citrobacter diversus, and $60 \%$ of Proteus mirabilis samples were sensitive to peracetic acid, meanwhile, all microbes were resistant to feracrylum $1 \%$ dan $\mathrm{NaCl}$ as controls,. Conclusion: Peracetic acid was more effective than feracrylum $1 \%$ as topical antimicrobial for diabetic ulcer.
\end{abstract}

Keywords: diabetic ulcer, microbe, topical antimicrobial agent

\begin{abstract}
Abstrak: Ulkus diabetik adalah suatu kondisi adanya infeksi, ulserasi dan atau kerusakan jaringan kulit yang lebih dalam yang berhubungan dengan kelainan neurologik serta berbagai tingkatan peripheral arterial disease (PAD) pada penderita diabetes melitus (DM). Ulkus diabetik lebih mudah terinfeksi karena respons kekebalan tubuh penderita DM biasanya menurun, bahkan kuman oportunistik juga dapat menjadi patogen. Infeksi masih menjadi masalah yang paling serius dialami penderita ulkus diabetik oleh karena biaya pengobatan yang besar dan waktu perawatan yang lama sehingga ulkus sering dibiarkan terinfeksi dengan komplikasi tanpa perawatan adekuat. Penelitian ini bertujuan untuk memperoleh data terkini pola kuman penderita ulkus diabetik dan untuk mengetahui efektivitas asam perasetik dan feracrylum pada pola kuman ulkus diabetik. Jenis penelitian ini ialah deskriptif analitik. Derajat ulkus dinilai dengan kriteria PEDIS. Spesimen pus diambil secara steril dengan media transpor, ditanam dalam mesin Baxtec, kemudian dilakukan identifikasi kuman dan uji sensitivitas terhadap asam perasetik dan feracrylum $1 \%$. Hasil penelitian memperlihatkan dari 57 penderita ulkus diabetik terbanyak ialah perempuan (36 penderita) dengan rerata usia 58,77 $\pm 9,077$ tahun. Sebagian besar ulkus diabetik (30 penderita) termasuk derajat 4. Hasil kultur memperlihatkan Proteus mirabilis (Gram negatif) yang tersering (17,5\%). Hasil uji sensitivitas pola kuman memperlihatkan 100\% sampel dari 12 jenis kuman, 83,3\% dari Citrobacter diversus, dan $60 \%$ dari Proteus mirabilis sensitif terhadap asam perasetik, sedangkan terhadap feracrylum $1 \%$ dan $\mathrm{NaCl}$ sebagai kontrol, seluruh kuman telah resisten. Simpulan: Asam perasetik lebih efektif dibandingkan feracrylum $1 \%$ sebagai antimikroba topikal pada ulkus diabetik.
\end{abstract}

Kata kunci: ulkus diabetik, mikroba, antimikroba topikal 
Ulkus diabetik adalah suatu kondisi adanya infeksi, ulserasi dan atau kerusakan jaringan kulit yang lebih dalam dan berhubungan dengan kelainan neurologis serta berbagai tingkatan peripheral arterial disease (PAD) pada penderita diabetes melitus (DM). Hiperglikemia pada DM yang tidak dikelola dengan baik akan menimbulkan berbagai komplikasi kronis seperti neuropati perifer dan angiopati. Dengan adanya angiopati dan neuropati perifer, trauma ringan dapat menimbulkan ulkus pada penderita DM.

Ulkus diabetik sendiri merupakan komplikasi menahun yang paling tidak disukai dan menakutkan bagi penderita DM; hal ini disebabkan waktu pengobatan yang lama, biaya pengobatan yang tinggi, dan bahaya amputasi serta sepsis akibat infeksi yang sulit ditanggulangi yang berakibat meningkatnya angka mortalitas. ${ }^{2}$

Prevalensi penderita DM dengan ulkus di dunia berkisar 4-10\%, menyebabkan 40$70 \%$ kasus dengan amputasi non-trauma. Penyebab amputasi pada penderita dengan ulkus diabetik ialah faktor iskemik 50-70\%, dan infeksi $30-50 \%$. Biaya perawatan penderita selama setahun di Amerika Serikat sebesar US\$ 13.179-23.372. ${ }^{3}$

Di Indonesia, prevalensi ulkus diabetik pada penderita DM sebesar $15 \%$ dengan angka kematian $32,5 \%$ dan amputasi sebesar $23,5 \%$, serta merupakan penyebab terbanyak perawatan penderita DM di rumah sakit yaitu sebesar $80 \%$, dengan besaran biaya perawatan seorang penderita berkisar 1,3-1,6 juta perbulan dan 43,5 juta pertahun. $^{4}$

Penderita dengan ulkus DM lebih mudah terinfeksi karena respons kekebalan tubuh biasanya menurun, bahkan kuman oportunistik juga dapat menjadi patogen pada penderita DM. Infeksi masih menjadi masalah yang paling serius dialami penderita ulkus diabetik oleh karena biaya pengobatan yang besar, dan waktu perawatan yang lama sehingga penderita sering membiarkan ulkus terinfeksi disertai komplikasi tanpa perawatan yang adekuat. Masalah ini masih menjadi kendala bagi tenaga kesehatan, khususnya di negara miskin dan berkembang. ${ }^{2}$

Tingginya angka morbiditas dan mortalitas akibat infeksi pada ulkus diabetik menjadi dasar bagi peneliti untuk mendapatkan pola kuman ulkus diabetik dan mencari solusi agen antimikroba topikal yang efektif, efisien, aman, mudah diperoleh dengan harga terjangkau yang dapat membantu dalam pengobatan dan perawatan infeksi kulit dan jaringan lunak. Dengan mendapatkan pola kuman dilanjutkan dengan uji sensitivitas terhadap antimikroba dapat diketahui seberapa besar efektivitas antimikroba tersebut sehingga dapat ditemukan antimikroba yang efektif untuk penderita ulkus diabetik.

\section{METODE PENELITIAN}

Jenis penelitian ini ialah deskriptif analitik mengenai gambaran pola kuman ulkus diabetik serta efektivitas asam perasetik dan feracrylum terhadap pola kuman ulkus diabetik. Penelitian dilakukan terhadap 57 penderita yang memenuhi kriteria inklusi dari bulan April-September 2015 di RSUP Prof. Dr. R. D. Kandou Manado. Derajat ulkus dinilai berdasarkan kriteria PEDIS. Spesimen yang dikultur ialah pus yang diambil dengan kapas steril dan media transpor. Cara identifikasi kuman dan uji sensitivitas ialah sebagai berikut: Dilakukan swab pus lalu ditanam dalam mesin Baxtec. Kuman yang tumbuh diidentifikasi. Bakteri Gram positif diidentifikasi dengan tes koagulasi dan katalase sedangkan bakteri Gram negatif diidentifikasi dengan tessimon sitrat, indol, fermentasi glukosa, dan iron agar test. Uji sensitivitas dilakukan dengan menanamkan koloni yang tumbuh pada media yang telah diletakkan di cakram antimikroba asam perasetik dan feracrylum $1 \%$ dan dinilai setelah 24 jam.

\section{HASIL PENELITIAN}

\section{Data demografi penderita}

Karakteristik penderita dikelompokkan atas usia, jenis kelamin, dan derajat infeksi menurut sistem klasifikasi PEDIS seperti terlihat pada Tabel 1, 2, dan 3. Dari data 
karakteristik penderita didapatkan rentang usia 35-76 tahun dengan jenis kelamin perempuan lebih banyak dibandingkan laki-laki (Tabel 1).

Tabel 1. Usia penderita ulkus diabetik

\begin{tabular}{lc}
\hline \multicolumn{1}{c}{ Usia } & Tahun \\
\hline Termuda & 35 \\
Tertua & 76 \\
Usia rata-rata & 58,77 \\
Simpangan baku & 9,077 \\
\hline
\end{tabular}

Tabel 2. Jenis kelamin penderita ulkus diabetik

\begin{tabular}{lcc}
\hline \multicolumn{1}{c}{ Jenis kelamin } & Jumlah & $\%$ \\
\hline Laki-laki & 21 & 36,8 \\
Perempuan & 36 & 63,2 \\
Total & 57 & 100 \\
\hline
\end{tabular}

Berdasarkan tabel derajat infeksi menurut sistem PEDIS, penderita ulkus diabetik terbanyak pada derajat 4 yaitu 30 penderita $(52,5 \%)$, diikuti derajat 3 sebanyak 23 penderita $(40,4 \%)$.

Tabel 3. Derajat Infeksi berdasarkan sistem PEDIS

\begin{tabular}{lcc}
\hline Derajat Infeksi & Jumlah & $\%$ \\
\hline Derajat 1 & 0 & 0 \\
Derajat 2 & 4 & 7,0 \\
Derajat 3 & 23 & 40,4 \\
Derajat 4 & 30 & 52,6 \\
Total & 57 & 100 \\
\hline
\end{tabular}

\section{Gambaran pola kuman ulkus diabetik}

Hasil kultur terhadap pus penderita ulkus diabetik memperlihatkan pola kuman yang terbanyak ialah Proteus mirabilis sebanyak 10 penderita $(17,5 \%)$ yang bersifat anaerob dengan Gram negatif (Tabel 4).

Berdasarkan sifat Gram kuman, diperoleh hasil kuman Gram negatif lebih banyak dibandingkan kuman gram positif (Tabel 5).

Dari Tabel 6 terlihat pada semua derajat infeksi berdasarkan sistem PEDIS bahwa pola kuman menunjukkan kuman dengan Gram negatif lebih banyak dibandingkan kuman Gram positif.

Tabel 4. Pola kuman ulkus diabetik

\begin{tabular}{lcc}
\hline \multicolumn{1}{c}{ Jenis kuman } & Jumlah & $\%$ \\
\hline Proteus mirabilis & 10 & 17,5 \\
Pseudomonas aeroginosa & 7 & 12,3 \\
Citrobacter diversus & 6 & 10,5 \\
Enterobacter aerogenes & 6 & 10,5 \\
Staphylococcus aureus & 6 & 10,5 \\
Klebsiela pneumonia & 4 & 7,0 \\
Staphylococcus epidirmidis & 3 & 5,3 \\
Streptococcus epidirmidis & 3 & 5,3 \\
Eschericia coli & 3 & 5,3 \\
Proteus Vulgaris & 3 & 5,3 \\
Citrobacter freundii & 2 & 3,5 \\
Serratia odorifera & 1 & 1,8 \\
Enterobacter gergoviae & 1 & 1,8 \\
Providencia rettgeri & 1 & 1,8 \\
Alcaligenes faecali & 1 & 1,8 \\
Total & 57 & 100 \\
\hline
\end{tabular}

Tabel 5. Pola kuman berdasarkan sifat Gram

\begin{tabular}{lcc}
\hline \multicolumn{1}{c}{ Gram } & Jumlah & $\%$ \\
\hline Positif (+) & 12 & 21,1 \\
Negatif (-) & 45 & 78,9 \\
Total & 57 & 100 \\
\hline
\end{tabular}

Tabel 6. Pola Kuman berdasarkan sifat Gram terhadap derajat infeksi

\begin{tabular}{lccc}
\hline Derajat infeksi & \multicolumn{2}{c}{ Gram } & Total \\
\cline { 2 - 3 } & Negatif & Positif & \\
Derajat 1 & 0 & 0 & 0 \\
Derajat 2 & 3 & 1 & 4 \\
Derajat 3 & 17 & 6 & 23 \\
Derajat 4 & 25 & 5 & 30 \\
Total & 45 & 12 & 57 \\
\hline
\end{tabular}

Data uji sensitivitas asam perasetik dan feracrylum pada pola kuman ulkus diabetik

Data Tabel 7 memperlihatkan hasil uji sensitivitas pola kuman terhadap asam perasetik yaitu sensitivitas $100 \%$ dari 12 jenis kuman, sensitivitas $83,3 \%$ dari Citrobacter diversus, dan sensitivitas $60 \%$ dari Proteus mirabilis sedangkan feracrylum $1 \%$ menunjukkan hasil resisten terhadap seluruh pola kuman. 
Tabel 7. Uji Sensitivitas Asam Perasetik dan Feracrylum $1 \%$ terhadap pola kuman ulkus diabetik

\begin{tabular}{|c|c|c|}
\hline Jenis Kuman & $\begin{array}{c}\text { Asam } \\
\text { perasetik }\end{array}$ & $\begin{array}{c}\text { Feracrylum } \\
1 \%\end{array}$ \\
\hline & $\begin{array}{l}\text { Sensitif } \\
(\%)\end{array}$ & $\begin{array}{c}\text { Resisten } \\
(\%)\end{array}$ \\
\hline Proteus Mirabilis & 60 & 100 \\
\hline $\begin{array}{l}\text { Pseudomonas } \\
\text { auroginosa }\end{array}$ & 100 & 100 \\
\hline $\begin{array}{l}\text { Citrobacter } \\
\text { diversus }\end{array}$ & 83,3 & 100 \\
\hline $\begin{array}{l}\text { Enterobacter } \\
\text { aerogenes }\end{array}$ & 100 & 100 \\
\hline $\begin{array}{l}\text { Staphylococcus } \\
\text { aureus }\end{array}$ & 100 & 100 \\
\hline $\begin{array}{l}\text { Klebsiela } \\
\text { pneumonia }\end{array}$ & 100 & 100 \\
\hline $\begin{array}{l}\text { Staphylococcus } \\
\text { epidirmidis }\end{array}$ & 100 & 100 \\
\hline Streptococcus sp & 100 & 100 \\
\hline Eschericia coli & 100 & 100 \\
\hline Proteus vulgaris & 100 & 100 \\
\hline Citrobacter freundii & 100 & 100 \\
\hline $\begin{array}{l}\text { Enterobacter } \\
\text { gergoviae }\end{array}$ & 100 & 100 \\
\hline Providencia rettgeri & 100 & 100 \\
\hline Alcaligenes faecalis & 100 & 100 \\
\hline
\end{tabular}

Tabel 8 memperlihatkan perbedaan proporsi resistensi bermakna $(\mathrm{p}<0,05)$ didapatkan pada kuman Pseudomonas aeroginosa, Enterobacter aerogenes, dan Staphylococcus aureus.

Tabel 8. Hasil pengujian perbedaan proporsi resistensi antara Asam Perasetikdan Feracrylum

\begin{tabular}{ll}
\hline \multicolumn{1}{c}{ Jenis Kuman } & Kemaknaan \\
\hline Proteus mirabilis & $\mathrm{p}=0,223$ \\
Pseudomonas auroginosa & $\mathrm{p}=0,022$ \\
Citrobacter diversus & $\mathrm{p}=0,125$ \\
Enterobacter aerogenes & $\mathrm{p}=0,040$ \\
Staphylococcus aureus & $\mathrm{p}=0,040$ \\
Klebsiela pneumonia & $\mathrm{p}=0,123$ \\
Staphylococcus epidirmidis & $\mathrm{p}=0,211$ \\
Streptococcus sp & $\mathrm{p}=0,211$ \\
Eschericia coli & $\mathrm{p}=0,211$ \\
Proteus vulgaris & $\mathrm{p}=0,211$ \\
Citrobacter freundii & $\mathrm{p}=0,359$ \\
Enterobacter gergoviae & $\mathrm{p}=0,603$ \\
Providencia rettgeri & $\mathrm{p}=0,603$ \\
Alcaligenes faecalis & $\mathrm{p}=0,603$ \\
\hline
\end{tabular}

\section{BAHASAN}

Diabetes melitus merupakan penyakit kronis progresif yang menjadi salah satu permasalahan medis, bukan hanya karena prevalensinya yang meningkat dari tahun ke tahun, tetapi juga karena penyakit ini umumnya dapat bermanifestasi ke gangguan penyakit sistemik lain seperti kelainan makrovaskuler dan mikrovaskuler. $^{3}$

Pada tahun 2012, dikatakan prevalensi angka kejadian diabetes melitus di dunia sebanyak 371 juta jiwa, dimana proporsi kejadian diabetes melitus tipe 2 (DMT2) ialah $95 \%$ dari populasi dunia yang menderita diabetes melitus dan hanya 5\% dari jumlah tersebut yang menderita diabetes melitus tipe 1. Menurut laporan World Health Organization (WHO), pada tahun 2000 sebanyak 171 juta jiwa menderita DMT2 dan diperkirakan pada tahun 2030 akan terjadi peningkatan sebanyak 195 juta jiwa penderita baru DMT2. ${ }^{3,4}$ Berdasarkan studi populasi DMT2 di berbagai Negara oleh WHO menunjukkan jumlah penderita diabetes mellitus pada tahun 2000 di Indonesia menempati urutan ke-4 terbesar dengan 8,426 juta orang dan diperkirakan akan menjadi sekitar 21,257 juta orang pada tahun 2030 dengan peningkatan $152 \%{ }^{4}$

WHO memperkirakan ada sekitar 194 juta jiwa atau $5,1 \%$ dari populasi penduduk dunia usia 20-79 tahun yang menderita diabetes melitus dan pada tahun 2025 diperkirakan akan meningkat menjadi 333 juta jiwa. ${ }^{3,4}$ Dari hasil penelitian yang dilakukan terhadap penderita ulkus diabetik, sebaran usia penderita ulkus diabetik mulai dari usia 35 tahun sampai 76 tahun dengan usia rata-rata 58-59 tahun. Manginstar ${ }^{5}$ melaporkan di tahun 2013, usia rata-rata penderita ulkus diabetik 5657 tahun, sesuai dengan data dari WHO bahwa diabetes melitus dimulai dari usia dewasa muda sampai usia tua, dengan prevalensi yang meningkat sesuai dengan semakin tua usia penderita. Prevalensi dari komplikasi ulkus diabetik meningkat 3\% pada penderita diabetes melitus usia di atas 
40 tahun dan menjadi $6 \%$ pada usia di atas 60 tahun. $^{4}$

Adanya globalisasi dan perubahan gaya hidup (diet tinggi lemak dan aktivitas fisik rendah) menyebabkan peningkatan kejadian overweight dan obesitas. Kedua hal tersebut diketahui merupakan faktor risiko DMT2, sehingga dengan semakin banyak orang yang mengalami overweight dan obesitas, semakin banyak pula orang yang menderita diabetes melitus. ${ }^{4}$

Dari 57 penderita ulkus diabetik yang memenuhi kriteria inklusi, terdapat 21 penderita laki-laki $(36,8 \%)$ dan 36 penderita perempuan (63,2\%). Hasil penelitian ini tidak berbeda dengan penelitian sebelumnya yang dilakukan Manginstar $^{5}$ sebanyak $68 \%$ penderita perempuan dan $32 \%$ penderita laki-laki. Penelitian lain yang dilakukan di RSUP Dr. M. Djamil Padang melaporkan hasil $71 \%$ penderita laki-laki dan $29 \%$ penderita perempuan, sedangkan di RS Dr. Kariadi Semarang mendapatkan hasil $42 \%$ laki-laki dan $58 \%$ perempuan, RS Dr. M. Hoesin Palembang mendapatkan hasil 40,3\% lakilaki dan $59,7 \%$ perempuan. ${ }^{6}$ Berdasarkan prevalensi dari WHO dikatakan bahwa prevalensi pada laki-laki dan perempuan sama, kecuali pada usia di atas 60 tahun lebih tinggi pada laki-laki dibanding perempuan. $^{4}$

Invasi jaringan kulit oleh mikroorganisme yang awalnya fisiologik dapat menjadi patogen pada ulkus diabetik disebabkan oleh faktor iskemik, neuroiskemik, maupun neuropati, diikuti oleh respon inflamasi lokal maupun sistemik disertai adanya kolonisasi bakteri. ${ }^{3}$

Sistem klasifikasi untuk memfasilitasi penelitian derajat infeksi pada ulkus diabetik telah dikembangkan oleh International Working Group of the Diabetic Foot yaitu sistem PEDIS (Perfusion, Extent, Depth/tissue loss, Infection, Sensation). ${ }^{7}$ Berdasarkan klasifikasi derajat infeksi pada ulkus diabetik menurut sistem PEDIS, persentase terbesar ialah ulkus derajat $4(52,5 \%)$, diikuti derajat $3(40,4 \%)$, dan derajat $2(7,0 \%)$. Hasil penelitian ini tidak berbeda dengan penelitian yang dilakukan Manginstar ${ }^{5}$ di tahun 2013, bahwa penderita yang datang berobat berada dalam kondisi ulkus dengan infeksi berat dengan respon inflamasi sistemik (derajat 4), diikuti dengan derajat 3 dimana infeksi telah mengenai jaringan subkutis, otot dan dapat lebih dalam sampai ke tulang, dengan tanda-tanda infeksi lokal yang jelas serta eritema dengan ukuran lebih dari $2 \mathrm{~cm}$. Pada penelitian yang dilakukan di RSUP Dr. M. Djamil Padang tahun 2008, persentase terbesar pada derajat $3(55 \%)$, diikuti derajat $4(37 \%)$, dan derajat $2(8 \%)$. Kondisi ini menjadi dasar tingginya angka kematian dan amputasi di Indonesia sebesar 32,5\% dan $23,5 \%$, dan merupakan penyebab terbanyak perawatan penderita DM di rumah sakit yaitu sebesar $80 \%$, dengan besaran biaya perawatan seorang penderita berkisar 1,31,6 juta rupiah perbulan dan 43,5 juta per tahun. ${ }^{6}$

Pada penelitian ini, kuman patogen terbanyak yang ditemukan pada ulkus diabetik ialah Proteus mirabilis, Pseudomonas aeroginosa, Citrobacter diversus, Enterobacter aerogenes (Gram negatif), dan Staphylococcus aureus (Gram positif). Hal ini sesuai dengan acuan pustaka yang menyatakan bahwa infeksi pada ulkus diabetik bersifat polibakteri yang dibuktikan dari beberapa hasil percobaan kultur pus terinfeksi ditemukan $4,1-5,8$ jenis kuman. ${ }^{8}$

Distribusi pola kuman ulkus diabetik yang didapatkan pada penelitian ini menunjukkan jenis kuman yang sama dengan perbedaan persentase kuman terbanyak dibandingkan penelitian sebelumnya yaitu Enterobacter aerogenes, Staphylococcus aureus, Proteus Mirabilis, dan Citrobacter diversus. ${ }^{5}$ Decroli et al. ${ }^{6}$ di RSUP Dr. M. Djamil Padang mendapatkan jenis kuman berdasarkan persentase terbanyak ialah Klebsiella sp, Proteus mirabilis, dan Staphylococcus aureus. Sugiyanto et al. di RS Dr. Kariadi Semarang mendapatkan jenis kuman Escherichia coli, Alcaligenes faecalis, Proteus sp, dan Proteus mirabilis. Dian et al. di RS Dr. M. Hoesin Palembang 
mendapatkan jenis kuman penyebab infeksi ulkus diabetik terbanyak ialah Staphylococcus aureus, Klebsiella pneumonia, Pseudomonas aeroginosa, Escherichia coli, dan Proteus mirabilis. ${ }^{6}$ Dari beberapa penelitian yang dilakukan didapatkan bahwa jenis kuman terbanyak penyebab ulkus diabetik hampir sama antara satu penelitian dengan lainnya.

Pada penelitian ini, dari 57 penderita didapatkan hasil kuman Gram negatif dengan persentase tertinggi yaitu $78,9 \%$. Hasil ini sesuai dengan acuan pustaka yang menyatakan bahwa kuman Gram negatif lebih sering menyebabkan infeksi dan biasanya pada keadaan infeksi yang berat disertai adanya jaringan nekrotik atau gangren. ${ }^{6}$

Pada penelitian ini, data hasil uji sensitivitas terhadap agen anti mikroba asam perasetik dengan persentase sensitivitas $100 \%$ pada 13 jenis kuman (52 sampel), 83,3\% pada Citrobacter diversus, dan $60 \%$ pada Proteus mirabilis, sedangkan agen anti mikroba feracrylum $1 \%$ dan $\mathrm{NaCl} 0,9 \%$ yang digunakan sebagai kontrol menunjukkan hasil $100 \%$ resisten ditandai dengan tidak terbentuknya zona hambat kuman pada uji sensitivitas yang dilakukan.

Berdasarkan hasil uji statistik perbedaan proporsi resistensi antara asam perasetik, feracrylum $1 \%$, dan $\mathrm{NaCl} 0,9 \%$ dengan nilai bermakna $\mathrm{p}<0,05$, yaitu pada Pseudomonas aeroginosa, Enterobacter aerogenes, dan Staphylococcus aureus. Hasil ini sama dengan penelitian Manginstar ${ }^{5}$ sebelumnya, bahwa terhadap Enterobacter aerogenes, asam perasetik memiliki tingkat efektivitas tertinggi, sedangkan terhadap Pseudomonas aeroginosa dan Staphylococcus aureus, asam perasetik memiliki efektivitas yang tidak berbeda bermakna dengan salah satu senyawa pembentuknya yaitu hidrogen peroksida. ${ }^{5}$

Asam perasetik yang terbentuk dari reaksi antara hidrogen peroksida 3\% dan asam asetat $5 \%$ menghasilkan reaksi yang bersifat reversibel antara reaktan dengan produk yang terbentuk setelah tercapainya keseimbangan kimia. Kelebihan asam perasetik ialah tidak dapat diinaktivasi oleh enzim katalase dan peroksidase. Selain itu reaktan yang terdiri atas asam asetat dan hidrogen peroksida masih tetap terbentuk (reaksi reversibel) dengan konsentrasi yang lebih rendah dari konsentrasi sebelumnya turut menambah efektivitas anti mikroba lewat sinergisme. ${ }^{9}$

Penelitian yang dilakukan Gogte et al. dan Gangal et al. untuk melihat aktivitas bakterisidal feracrylum terhadap bakteri Gram negatif, Gram positif, dan beberapa jamur, secara elektromikroskpoik mengungkapkan terjadinya lisis dari dinding sel bakteri tersebut disertai ejeksi sel mast dan terbentuknya vakuol. Bhagwat et al. membandingkan aktivitas feracrylum dengan povidon iodin dan melaporkan walaupun dalam konsentrasi yang tinggi keduanya memiliki aktivitas bakterisidal yang sama, namun dalam konsentrasi yang rendah feracrylum memiliki aktivitas bakterisidal yang secara signifikan lebih efektif. Infeksi yang terjadi, khususnya oleh streptococcus, menghambat terjadi epitelisasi dan memengaruhi proses penyembuhan. Vermadan Patel et al. menilai efektivitas feracrylum dalam penyembuhan luka dan melaporkan proses penyembuhan lebih baik dengan feracrylum; jaringan granulasi terlihat pada hari ke-5 dan tidak ditemukan infeksi dibandingkan dengan kelompok kontrol yang menerima cairan antiseptik standar (povidon iodin). ${ }^{10-12}$

Belum ada laporan penelitian mengenai perbandingan uji kepekaan antara asam perasetik dan feracrylum pada pasien dengan ulkus diabetik terinfeksi, sehingga hasil uji kepekaan yang didapatkan bisa menjadi dasar acuan dalam pemilihan antimikroba topikal bagi penderita ulkus diabetik. Asam perasetik yang memiliki sensitivitas $100 \%$ pada sebagian besar kuman ulkus diabetik merupakan senyawa buatan yang sampai saat ini belum tersedia dalam kemasan siap pakai sedangkan feracrylum $1 \%$ tersedia dalam kemasan siap pakai, mudah di dapat, dan sering digunakan untuk penanganan ulkus diabetik di rumah sakit. 


\section{SIMPULAN}

Berdasarkan data demografi, penderita ulkus DM dimulai dari usia dewasa muda sampai usia tua, dengan jumlah perempuan lebih banyak dibandingkan laki-laki. Sebagian besar penderita datang berobat dalam kondisi infeksi lanjut (PEDIS derajat $3 \& 4$ ) dimana infeksi yang ditemukan pada ulkus DM bersifat polibakteri yang bersifat gram negatif. Dari hasil uji sensitivitas ditemukan bahwa asam perasetik lebih efektif dibandingkan feracrylum $1 \%$ sebagai antimikroba topikal pada ulkus DM.

\section{DAFTAR PUSTAKA}

1. Powers AC. Diabetes mellitus. In: Harrison's Principles of Internal Medicine (16th ed). New York: McGraw-Hill Co. 2005. p.2152-79

2. Tsapogas P. Infection. In: Nicholas K, Eleftherios D, Konstantinus M, Nicholas T, Panagiotis T, editors. Atlas of the Diabetic Foot. Oxford: John Wiley \& Sons Inc., 2010; p.169-94.

3. Clayton W, Elasy T. A review of the pathophysiology, classification, and treatment of foot ulcers in diabetic patients. Clinical Diabetes. 2009;27(2):52-8.

4. PERKENI. Konsensus Pengelolaan dan Pencegahan Diabetes Melitus Tipe 2 di Indonesia. Jakarta, 2011; p. 1-25.

5. Manginstar C, Sapan H, Sumangkut R, Ngantung $\mathbf{J}$, Waworuntu $\mathbf{L}$, Lolombulan J. Uji sensitivitas cuka 5\%, hidrogen peroksida 3\% dan asam perasetik terhadap pola kuman penderita ulkus diabetik di RSUP Prof. Dr. R. D. Kandou Manado [Karya akhir]. Manado: FK Unsrat; 2013. p.3146.

6. Decroli E, Karimi J, Manaf A, Syahbuddin S. Profil ulkus diabetik pada penderita rawat inap di Bagian Penyakit Dalam RSUP Dr. M. Djamil Padang. Maj Kedokt Indon. 2008;58(1):1-7.

7. Tentolouris N. Introduction. In: Nicholas K, Elefftherios D, Konstantinus $\mathrm{M}$, Nicholas T, Panagiotis T, editors. Atlas of the Diabetic Foot. Oxford: John Wiley \& Sons Inc., 2010; p.1-10.

8. Adolf W, Karchmer. Microbiology and treatment of diabetic foot infections. In: Aristidis V, John M, Frank W, editors. The Diabetic Foot Medical and Surgical Management. Totowa: Humana Press Inc., 2002; p. 207-21.

9. Beiring H. More than 100 years of peracetic acid an old active substance with a bright future. Aseptica. November 2005:14-9.

10. Hathial. Feracrylum: A therapeutic profile. The Indian Practitioner. 2000;53(4):267-9.

11. SPC Biokinetic Study Centre. To elucidate possible mechanism of action of feracrylum as a bactericidal agent Mumbai; Patel Research Center, 2001.

12. Rao AM, Patel RV. Sepgard Gel (feracrylum 1\%) in the local management of wounds. Indian Medical Gazette. 2004:CXXXVIII(12):518-21. 